\title{
Impact of Li addition in Al-rich alloys for hydrogen production in water
}

\author{
Tiantian $\mathrm{He}^{\mathrm{a}}$, Yi Xiong ${ }^{\mathrm{b}}$, Sanming Du ${ }^{\mathrm{a}, \mathrm{b}}$, Zhenjun Yuan ${ }^{\mathrm{a}}$, Xinyu Liang ${ }^{\mathrm{b}}$, Marko Huttula ${ }^{\mathrm{c}}$, Wei Cao ${ }^{\mathrm{c}, \mathrm{d}}$ \\ a National United Engineering Laboratory for Advanced Bearing Tribology, Henan University of Science and \\ Technology, Luoyang 471023, China \\ ${ }^{\mathrm{b}}$ School of Materials Science and Engineering, Henan University of Science and Technology, Luoyang 471023, China \\ ${ }^{c}$ Nano and Molecular Systems Research Unit, University of Oulu, FIN-90014, Finland \\ ${ }^{\mathrm{d}}$ School of Mechanical and Automotive Engineering, Anhui Polytechnic University, Wuhu 241000, Anhui, China \\ Corresponding author. Tel.: +86379 64231723; fax: +8637964231723. \\ E-mail address: tthe@ haust.edu.cn (Tiantian He)
}

\begin{abstract}
In this study, three types of aluminum alloys (Al-Li, Al-Ga-In-Sn, Al-Li-Ga-In-Sn alloys) were prepared via vacuum arc melting technology. The microstructures of the alloys were examined by X-ray diffraction (XRD), scanning electron microscopy (SEM) and energy dispersive spectroscopy (EDX). The water discharge method was used to evaluate the water-aluminum reaction. The results show that the Al-Li alloy is inert in aqueous ambience, whereas the Al-Ga-In-Sn alloy and Al-Li-Ga-In-Sn alloy rapidly react with water. Meanwhile, the Li addition hinders the aluminum-water reaction mainly due to the formation of $\mathrm{AlLi}$ and $\mathrm{Li}_{5} \mathrm{Sn}_{2}$ intermetallic compounds, which causes a lower $\mathrm{H}_{2}$ generation rate and a lower $\mathrm{H}_{2}$ yield of Al-Li-Ga-In-Sn alloys than that of the Al-Ga-In-Sn alloy.
\end{abstract}

Key words: Al-rich alloy, low melting point phase, microstructure, aluminum-water reaction.

\section{Introduction}

Hydrogen is widely accepted as a renewable and ideal fuel, due to its high caloric content, abundant resources, and environmental friendly features [1-5]. Currently, it is considered a future alternative of the conventional fossil fuel. However, the hydrogen production, safe storage, transportation, and delivery limit the hydrogen value chain and applications. At present, the generation of hydrogen by the hydrolysis of metal or metal hydrides has attracted much attention from scientists [6-11]. Among the available methods, Al metal or alloys can directly generate hydrogen from 
water due to its high energy storage, light weight, natural abundance, environmental safety of the reaction products, and low cost. However, the stable alumina film on the Al surface prevents the Al-water reaction. Thus, high temperature is normally required for the reaction [12-20].

To circumvent the blockages of the passive oxide on Al, the metal was alloyed with low melting point counterparts such as Ga, In and Sn [21-23]. Woodall [24] suggested that the Al-Ga-In-Sn alloy has considerable reactivity. It can directly react with the water under normal conditions, and these alloys yield higher reactivity. The intermetallic compounds formed with $\mathrm{Ga}$, In and $\mathrm{Sn}$ at the grain boundary prevent the Al passivation, and provide transportation routes of $\mathrm{Al}$ to reach the reaction sites. As a result, the reaction process is repeated until most or all of $\mathrm{Al}$ atoms are consumed by the reaction. In recent years, Wang et al. [25-28] prepared Al-Ga-In-Sn quaternary alloys with different compositions by using the traditional smelting process (arc melting and induction melting), and studied the microstructure and phase composition of alloys, including the melting point of Ga-In-Sn (GIS) phase. A low melting point Ga-In-Sn phase in alloys was identified with a melting point near $10.7{ }^{\circ} \mathrm{C}$, which further demonstrated the mechanism of the Al-water reaction proposed by Woodall. Meanwhile, the $\mathrm{H}_{2}$ evolution rate was found to be closely relevant to the microstructure of alloys. The size of the $\mathrm{Al}$ grains and the composition, size and number of the Ga-In-Sn phase are the key factors to control the reaction rate of $\mathrm{Al}$ and water. These works provide a preliminary research background of the relationship between the microstructure, composition, preparation process and the Al-water reaction of alloys. However, in practical applications, the reaction temperature, reaction rate and $\mathrm{H}_{2}$ yield of Al-water gain are also key factors for hydrogen production. For example, if hydrogen is used as a portable energy source, the reaction temperature and $\mathrm{H}_{2}$ generation rate must be controlled. Therefore, it is necessary to find the key factors and rules to control the $\mathrm{Al}$-water reaction.

It is well known that the chemically active Li metal can vigorously react with water to produce hydrogen. Due to its light weight, it has a high hydrogen storage capacity. Therefore, the addition of Li to the Al-rich alloy may accelerate the $\mathrm{Al}$-water reaction. In addition, $\mathrm{Li}$ and $\mathrm{Al}$ may form intermetallic compounds such as $\mathrm{AlLi}, \mathrm{Al}_{2} \mathrm{Li}_{3}$ and 
$\mathrm{Al}_{4} \mathrm{Li}_{9}$. These intermetallic compounds precipitate on the aluminum grain boundaries, which affect the formation and distribution of GIS phases. The Al-water reaction is inevitably affected when the direct contact between the $\mathrm{Al}$ grains and the GIS phases is cut off by these compounds.

In this paper, Al-Li, Al-Ga-In-Sn and Al-Li-Ga-In-Sn alloys were prepared by vacuum arc melting technology. The microstructure and phase composition of Al-Li, Al-Ga-In-Sn and Al-Li-Ga-In-Sn alloys were systematically studied, and the Al-water reaction of alloys at different water temperatures was investigated. The effect of alloying element $\mathrm{Li}$ on the hydrolysis of aluminum alloy was explored. The mechanism of hydrogen production by the hydrogenation of the aluminum alloy was revealed, and the composition ratio of aluminum alloy was further optimized. The results serve as a theoretical and experimental starting point for the control of the Al-water reaction and broaden the practical application of the alloy.

\section{Experimental details}

The Al-Li, Al-Ga-In-Sn and Al-Li-Ga-In-Sn alloys were synthesized by arc-melting. The nominal compositions of the alloy ingots are shown in Table 1. The charging materials are industrial pure $\mathrm{Al}$ and $\mathrm{Li}$ with over 99.9 wt.\% purity of $\mathrm{Ga}$, In and Sn. The alloy ingots (40 g in mass) were melted in a high-purity argon atmosphere in a water-cooled copper crucible several times to ensure the compositional homogeneity.

The phase compositions of the alloys were analyzed by X-ray diffraction (XRD) using a Rigaku D/max 2400 diffractometer with monochromated $\mathrm{CuK} \alpha$ radiation $(\mathrm{k} \alpha 1=0.154056 \mathrm{~nm})$. The microstructures of alloys were characterized using an FEI Inspect F50 scanning electron microscope (SEM) with a Quanta 600 EDX (Energy Dispersed X-ray) system. The fracture surfaces of samples were observed. To minimize the oxidation of the fresh fracture surface, all samples were placed into the sample chamber as soon as they were broken.

The water displacement method was used to measure the hydrogen generation rate of alloys. The equipment in the $\mathrm{H}_{2}$ generation is similar to that described in a previous study [27]. The sample was dropped into a $250 \mathrm{ml}$ Pyrex glass reactor (containing distilled water) on a water bath. The weight of the ejected water due to the $\mathrm{H}_{2}$ release was 
automatically recorded using a one ten-thousandth scale. The data and reaction time were stored in a computer. After the calibration of the recorded weight of ejected water, the water mass was converted to $\mathrm{H}_{2}$ generated volume under the standard conditions $(273 \mathrm{~K}, 1 \mathrm{~atm})$ using the ideal gas equation. The added mass was approximately $0.3 \mathrm{~g}$ for each experiment. The temperature of experiments was maintained constant at $20{ }^{\circ} \mathrm{C}$, and the humidity was below $20 \%$.

\section{Results and discussion}

\subsection{XRD analysis}

Fig. 1 shows the XRD patterns of Al-2Li, Al-6GIS, Al-2Li-6GIS alloys. All samples contain an Al (Ga) solid solution as a result of the partial dissolution of Ga into Al lattices. The AlLi phase is found in the Al-2Li alloy. According to the Al-Li binary phase diagram, when the Li content is higher than $5 \mathrm{wt} . \%$, the AlLi phase is formed due to the eutectic reaction [29]. However, a water-cooled copper crucible was used for alloy cooling in the present work. Thus, the formation of the AlLi phase in the Al-2Li alloy is mainly attributed to the nonequilibrium rapid solidification. Meanwhile, an $\mathrm{In}_{3} \mathrm{Sn}$ phase is found in the Al-6GIS alloy. The Al-2Li-6GIS alloy contains AlLi, $\mathrm{In}_{3} \mathrm{Sn}_{\text {and }} \mathrm{Li}_{5} \mathrm{Sn}_{2}$ phases. Moreover, the diffraction peaks of the AlLi phase in the Al-2Li-6GIS alloy are stronger than that in the Al-2Li alloy, mainly because some $\mathrm{Ga}$ is dissolved into $\mathrm{Al}$ lattices in the Al-2Li-6GIS alloy, which reduces the solid solution degree of $\mathrm{Li}$ in $\mathrm{Al}$ and yields more AlLi.

\subsection{SEM observations}

Fig. 2 shows the typical SEM morphologies of Al-2Li, Al-6GIS, Al-2Li-6GIS alloys. Due to a small load of Li in the Al-2Li alloy, the fracture morphology shows many dimples with an average size of $42 \pm 24 \mu \mathrm{m}$, as observed in Figs. 2a and b. Meanwhile, few bright white AlLi intermetallic compounds are precipitated near the dimple (Fig. 2 b). From Figs. 2c and d, the fracture morphology of the Al-6GIS alloy is a typical columnar structure with an average $\mathrm{Al}$ grain size (columnar width) of approximately $55 \pm 26 \mu \mathrm{m}$. Some bright white $\operatorname{In}_{3} S n$ phases are also found on the surface of the alloy. In Fig. 2e and f, Al grains of the Al-2Li-6GIS alloy remain columnar, which shows an obvious directional growth during the alloy solidification. However, compared with the grain in the Al-6GIS alloy, the present grain is 
shorter in length and wider in width $(106 \pm 26 \mu \mathrm{m})$ as shown in Fig. 2e. Figs. 2e and $\mathrm{f}$ also show that many bright white $\mathrm{In}_{3} \mathrm{Sn}$ and AlLi precipitates are distributed on the surface of the alloy.

The phase composition of the alloy was analyzed by EDX, and the results are shown in Table 2. No Li was observed in the Al-2Li alloy or Al-2Li-6GIS alloy mainly due to the EDX detection limits of the light elements below C. For the Al-6GIS and Al-2Li-6GIS alloys, a small amount of $\mathrm{Ga}$ is found in $\mathrm{Al}$ grains. In addition to $\mathrm{Al}$ and $\mathrm{Ga}$, intensive $\mathrm{O}$ is observed in the fracture after the oxidization of Al-6GIS and Al-2Li-6GIS alloys. For the Al-6GIS and Al-2Li-6GIS alloys, both In and Sn elements are observed in the bright white particles at the Al grain boundaries (GB). In combination to the XRD results, the bright white precipitation on the GB of the alloy contains the $\mathrm{In}_{3} \mathrm{Sn}$ phase. However, the atomic ratio of In:Sn approaches 1.7:1 (Al-6GIS alloy) and 6:1 (Al-2Li-6GIS alloy), which deviates from 3:1 and suggests that those phases also contain extra $\mathrm{In}$ or $\mathrm{Sn}$ in addition to $\mathrm{In}_{3} \mathrm{Sn}$.

3.3 Reactivity of alloys with water

The Al-2Li alloy did not react with water because there was a passive oxidization layer on the $\mathrm{Al}$ surface. However, once the Al-6GIS and Al-2Li-6GIS alloys contacted water, the alloys immediately reacted with water, and $\mathrm{H}_{2}$ bubbles began to incessantly flow from water. Fig. 3 shows the typical $\mathrm{H}_{2}$ production curves of $\mathrm{Al}-6 \mathrm{GIS}$ and Al-2Li-6GIS alloys at different water temperatures. The $\mathrm{H}_{2}$ generation rates and $\mathrm{H}_{2}$ yields of alloys were calculated from Fig. 3, and they are plotted in Fig. 4 and tabulated in Table 3. As shown in Fig. 3, the $\mathrm{H}_{2}$ generation rate and $\mathrm{H}_{2}$ yield of the Al-6GIS alloy are higher than those of the Al-2Li-6GIS alloy at the same temperature. At $50{ }^{\circ} \mathrm{C}$ water temperature, the Al-water reaction lasted approximately 200 min. The $\mathrm{H}_{2}$ yield of the Al-6GIS alloy is nearly $86 \%$. For the Al-2Li-6GIS alloy, the reaction time is about $480 \mathrm{~min}$ and the $\mathrm{H}_{2}$ yield is $84 \%$. At $70{ }^{\circ} \mathrm{C}$, the reaction times of the Al-6GIS alloy and Al-2Li-6GIS alloy are approximately $125 \mathrm{~min}$ and $225 \mathrm{~min}$, respectively. The $\mathrm{H}_{2}$ yields of both alloys reach 100\%. The results in Fig. 3 also demonstrate the importance of the water temperature during the Al-water reaction. The $\mathrm{H}_{2}$ generation rate and $\mathrm{H}_{2}$ yield increase with the reaction temperature.

The Li addition reduces the $\mathrm{H}_{2}$ generation rate of the Al-6GIS alloy. As given in Fig. 4, the maximum $\mathrm{H}_{2}$ 
generation rates are $13 \mathrm{ml} / \mathrm{min} \cdot \mathrm{g} \mathrm{Al}$ and $10 \mathrm{ml} / \mathrm{min} \cdot \mathrm{g} \mathrm{Al}$ for the $\mathrm{Al}-6 \mathrm{GIS}$ alloy and $\mathrm{Al}-2 \mathrm{Li}-6 \mathrm{GIS}$ at $50{ }^{\circ} \mathrm{C}$, respectively. When the water temperature is $60{ }^{\circ} \mathrm{C}$, the value increases to $27 \mathrm{ml} / \mathrm{min} \cdot \mathrm{g} \mathrm{Al}$ and $15 \mathrm{ml} / \mathrm{min} \cdot \mathrm{g} \mathrm{Al}$. When the water temperature further increases to $70{ }^{\circ} \mathrm{C}$, the maximum $\mathrm{H}_{2}$ generation rate of the $\mathrm{Al}-6 \mathrm{GIS}$ alloy and $\mathrm{Al}-2 \mathrm{Li}-6 \mathrm{GIS}$ alloy are $37 \mathrm{ml} / \mathrm{min} \cdot \mathrm{g} \mathrm{Al}$ and $17 \mathrm{ml} / \mathrm{min} \cdot \mathrm{g} \mathrm{Al}$. Thus, the $\mathrm{Li}$ addition hinders the Al-water reaction of the alloy, which causes a decrease in $\mathrm{H}_{2}$ generation rate and $\mathrm{H}_{2}$ yield. From the microstructure analysis, Li forms two intermetallic compounds $\mathrm{AlLi}$ and $\mathrm{Li}_{5} \mathrm{Sn}_{2}$ on the $\mathrm{Al}$ grain boundaries, which affect the formation and distribution of GIS phases, inhibits the Al-water reaction, and causes the decrease in the $\mathrm{H}_{2}$ generation rate and $\mathrm{H}_{2}$ yield.

\subsection{Byproducts of the reactions}

Fig. 5 shows the XRD patterns of the byproducts of Al-6GIS alloy and Al-2Li-6GIS alloy after the reaction with water at $60{ }^{\circ} \mathrm{C}$. The lack of $\mathrm{LiOH}$ phase in the figure indicates that $\mathrm{Li}$ does not react with water. The byproducts of the Al-water reaction of the alloy are mainly $\mathrm{Al}(\mathrm{OH})_{3}$ and $\mathrm{AlO}(\mathrm{OH})$. As shown in Fig. 5, the Al-2Li-6GIS alloy has more $\mathrm{Al}(\mathrm{OH})_{3}$ but less $\mathrm{AlO}(\mathrm{OH})$ than the $\mathrm{Al}-6 \mathrm{GIS}$ alloy, because the $\mathrm{Al}-6 \mathrm{GIS}$ alloy has a higher reaction rate, which generates substantial heat, and causes a rapid increase in local water temperature in favor of the $\mathrm{AlO}(\mathrm{OH})$ formation. Therefore, with the increase in water temperature, the byproducts of the Al-water reaction of the $\mathrm{Al}$ alloy gradually changes from $\mathrm{Al}(\mathrm{OH})_{3}$ to $\mathrm{AlO}(\mathrm{OH})$, which is consistent with the results of A.V. Ilyukhina [30]. They found that when the water temperature was below $25{ }^{\circ} \mathrm{C}$, the byproduct was $\mathrm{Al}(\mathrm{OH})_{3}$. When the water temperature was increased from $40{ }^{\circ} \mathrm{C}$ to $60{ }^{\circ} \mathrm{C}$, the byproduct became a mixture of $\mathrm{Al}(\mathrm{OH})_{3}$ and $\mathrm{AlO}(\mathrm{OH})$. The amount of $\mathrm{Al}(\mathrm{OH})_{3}$ decreased with the reaction temperature, whereas the amount of $\mathrm{AlO}(\mathrm{OH})$ increased. When the temperature was over $60{ }^{\circ} \mathrm{C}$, the byproduct was $\mathrm{AlO}(\mathrm{OH})$. The $\mathrm{In}_{3} \mathrm{Sn}$ phase is also detected in Fig. 5, which indicates that the low melting point metal does not react with water but only provides a passage for the Al-water reaction.

\section{Conclusions}

To conclude, the $\mathrm{Li}$ addition has great effects on the phase composition of Al-Li-Ga-In-Sn alloys. In ${ }_{3} \mathrm{Sn}$, AlLi and $\mathrm{Li}_{5} \mathrm{Sn}_{2}$ phases precipitate at the $\mathrm{Al}$ grain boundaries. Corresponding to the microstructures of alloys, the Li addition 
hinders the Al-water reaction of the alloy and reduces the $\mathrm{H}_{2}$ generation rate and yield. This phenomenon is attributed to AlLi and $\mathrm{Li}_{5} \mathrm{Sn}_{2}$ on the Al grain boundaries, which affect the formation and distribution of GIS phases. As a result, Al slowly reacts with water and some $\mathrm{Al}$ remains without consumption. In addition, the water temperature greatly affects the byproducts of the Al-water reaction. With the increase in water temperature, the byproducts of the Al-water reaction of the $\mathrm{Al}$ alloy gradually changes from $\mathrm{Al}(\mathrm{OH})_{3}$ to $\mathrm{AlO}(\mathrm{OH})$.

\section{Acknowledgments}

This work was financially supported by National Natural Science Foundation of China (Grant No. 51171201), National Basic Research Program of China (2010CB631305), the Key Scientific Research Projects in Henan Province (18B430007), the Academy of Finland (Grant No. 311934), the Program for Science, Technology Innovation Talents in Universities of Henan Province (17HASTIT026), Education Department of Henan Province (16A430005) and the Science and Technology Innovation Team of Henan University of Science and Technology (2015XTD006).

\section{References}

[1] S.H. Mohr, J. Wang, G. Ellem, J. Ward, D. Giurco, Projection of world fossil fuels by country, Fuel, 2015 (141): $120-135$

[2] N. Muradov, Low-carbon production of hydrogen from fossil fuels, Compendium of Hydrogen Energy, 2015: 489-522.

[3] G. Nicoletti, N. Arcuri, G. Nicoletti, R. Bruno, A technical and environmental comparison between hydrogen and some fossil fuels, Energy Conversion and Management, 2015 (89): 205-213.

[4] M. Ball, M. Weeda, The hydrogen economy-Vision or reality?, Compendium of Hydrogen Energy, 2016 (4): 237-266.

[5] S. Dutta, A review on production, storage of hydrogen and its utilization as an energy resource, Journal of Industrial and Engineering Chemistry, 2014 (20): 1148-1156.

[6] X.Y. Chen, Z.W. Zhao, M.M. Hao, D.Z. Wang, Hydrogen generation by splitting water with Al-Li alloys, International 
Journal of Energy Reaserch, 2013, 37(13): 1624-1634.

[7] S.K. Oh, M.J. Kim, K.S. Eom, J.S. Kyung, D.H. Kim, E.A. Cho, H.S. Kwon, Design of Mg-Ni alloys for fast hydrogen generation from seawater and their application in polymer electrolyte membrane fuel cells, International Journal of Hydrogen Energy, 2016 (41): 5296-5303.

[8] S. Liu, M.Q. Fan, C.Wang, Y.X. Huang, D. Chen, L.Q. Bai, K.Y. Shu , Hydrogen generation by hydrolysis of Al-Li-Bi-NaCl mixture with pure water, International Journal of Hydrogen Energy, 2012, 37(1):1014-1020.

[9] F. Xu, L.X. Sun, X.F. Lan, H.L. Chu, Y.J. Sun, H.Y. Zhou, F. Li, L.N. Yang, X.L. Si, J. Zhang, S. Walter, Z. Gabelica, Mechanism of fast hydrogen generation from pure water using $\mathrm{Al}-\mathrm{SnCl}_{2}$ and bi-doped $\mathrm{Al}_{-} \mathrm{SnCl} 2$ composites, International Journal of Hydrogen Energy, 2014 (39): 5514-5521.

[10] Z.Y. Deng, Y.B. Tang, L.L. Zhu, Y. Sakka, J. Ye, Effect of different modification agents on hydrogen-generation by the reaction of Al with water, International Journal of Hydrogen Energy, 2010 (35): 9561-9568.

[11] L. Soler, A.M. Candela, J. Macanás, M. Muñoz, J. Casado, Hydrogen generation from water and aluminum promoted by sodium stannate, International Journal of Hydrogen Energy, 2010 (35): 1038-1048.

[12] X.Y. Chen, Z.W. Zhao, X.H. Liu, M.M. Hao, A.L. Chen, Z.Y. Tang, Hydrogen generation by the hydrolysis reaction of ball-milled aluminium-lithium alloys, Journal of Power Sources, 2014,254:345-352.

[13] H. Wang, Y. Chang, S. Dong, Z. Lei, Q. Zhu, P. Luo, Z. Xie, Investigation on hydrogen production using multicomponent aluminum alloys at mild conditions and its mechanism, International Journal of Hydrogen Energy, 2013 (38): 1236-1243.

[14] M.Q. Fan, L.X. Sun, F. Xu, D.S. Mei, D. Chen, W.X. Chai, F.L. Huang, Q.M. Zhang, Microstructure of Al-Li alloy and its hydrolysis as portable hydrogen source for proton-exchange membrane fuel cells, International Journal of Hydrogen Energy, 2011, 36(16):9791-9798

[15] Y.Y. Jia, J. Shen, H.X. Meng, Y.M. Dong, Y.J. Chai, N. Wang, Hydrogen generation using a ball-milled $\mathrm{Al} / \mathrm{Ni} / \mathrm{NaCl}$ mixture, Journal of Alloys and Compounds, 2014, 588: 259-264. 
[16] H. Zou, S. Chen, Z. Zhao, W. Lin, Hydrogen production by hydrolysis of aluminum, Journal of Alloys and Compounds, 2013 (578): 380-384.

[17] A.O. Dudoladov, O.A. Buryakovskaya, M.S. Vlaskin, A.Z. Zhuk, E.I. Shkolnikov, Generation of hydrogen by aluminium oxidation in aquaeous solutions at low temperatures, International Journal of Hydrogen Energy, 2016 (41): $2230-2237$.

[18] Y.A. Liu, X.H. Wang, H.Z. Liu, Z.H. Dong, S.Q. Li, H.W. Ge, M. Yan, Effect of salts addition on the hydrogen generation of Al-LiH composite elaborated by ball milling, Energy, 2015 (89): 907-913.

[19] M.Q. Fan, S. Liu, C. Wang, D. Chen, K.Y. Shu, Hydrolytic hydrogen generation using milled aluminum in water activated by $\mathrm{Li}, \mathrm{In}$, and $\mathrm{Zn}$ additives, 2012, 12(4):642-648.

[20] H.B. Dai, G.L. Ma, H.J. Xia, P. Wang, Reaction of aluminium with alkaline sodium stannate solution as a controlled source of hydrogen, Energy and Environmental Science, 2011 (4): 2206-2212.

[21] J.T. Ziebarth, R. Kramer, J. Woodall, D. Sherman, G. Choi, C. Allen, J. Jeon, Splitting water with Al rich alloys: structure and reaction Kinetics, in: Meeting Abstracts, The Electrochemical Society, 2008, pp. 661-661.

[22] J.T. Ziebarth, J.M. Woodall, R.A. Kramer, G. Choi, Liquid phase-enabled reaction of Al-Ga and Al-Ga-In-Sn alloys with water, International Journal of Hydrogen Energy, 2011 (36): 5271-5279.

[23] J. Woodall, J.T. Ziebarth, C.R. Allen, D.M. Sherman, J. Jeon, G. Choi, Recent results on splitting water with aluminum alloys, Ceram Trans, 2009 (202): 121-127.

[24] J.M. Woodall, J. Ziebarth, C.R. Allen, The science and technology of Al-Ga alloys as a material for energy storage, transport, and splitting water, in: Proceedings of the ASME 2nd energy nanotechnology international conference, 2007.

[25] W. Wang, D.M. Chen, K. Yang, Investigation on microstructure and hydrogen generation performance of Al-rich alloys, International Journal of Hydrogen Energy, 2010 (35): 12011-12019.

[26] W. Wang, W. Chen, X.M. Zhao, D.M. Chen, K. Yang, Effect of composition on the reactivity of Al-rich alloys 
with water, International Journal of Hydrogen Energy, 2012 (37): 18672-18678.

[27] T.T. He, W. Wang, D.M. Chen, K. Yang, Reactivity of Al-rich alloys with water promoted by liquid Al grain boundary phases, Journal of Materials Science and Technology, 2017, 33: 397-403.

[28] W. Wang, X.M. Zhao, D.M. Chen, K. Yang, Insight into the reactivity of Al-Ga-In-Sn alloy with water, International Journal of Hydrogen Energy, 2012 (37): 2187-2194.

[29] N.E. Prasad, T.R. Ramachandran, Chapter 3: Phase diagrams and phase reactions in Al-Li, Alloys Aluminum-lithium Alloys, 2014, 61-97.

[30] A.V. Ilyukhina, O.V. Kravchenko, B.M. Bulychev, E.I. Shkolnikov, Mechanochemical activation of aluminm with gallams for hydrogen evolution from water, International Journal of Hydrogen Energy, 2010 (35): 1905-1910. 


\section{Table captions:}

Table 1 Nominal compositions of the prepared alloy ingots (wt.\%).

Table 2 Compositions of the alloys obtained using EDX.

Table $3 \mathrm{H}_{2}$ yields of the alloys at different water temperatures (\%).

\section{Figure captions:}

Fig. 1 XRD patterns of different alloys.

Fig. 2 Fracture surfaces of different alloys: (a), (b) Al-2Li alloy; (c), (d) Al-6GIS alloy; (e), (f) Al-2Li-6GIS alloy.

Fig. $3 \mathrm{H}_{2}$ production curves of the Al-6GIS alloy and Al-2Li-6GIS alloy measured at different water temperatures: (a)

$50{ }^{\circ} \mathrm{C}$; (b) $60{ }^{\circ} \mathrm{C}$; (c) $70{ }^{\circ} \mathrm{C}$.

Fig. $4 \mathrm{H}_{2}$ generation rates of the alloys at different water temperatures.

Fig. 5 XRD patterns of the byproducts of the Al-6GIS alloy and Al-2Li-6GIS alloy after the reaction with water at $60{ }^{\circ} \mathrm{C}$. 


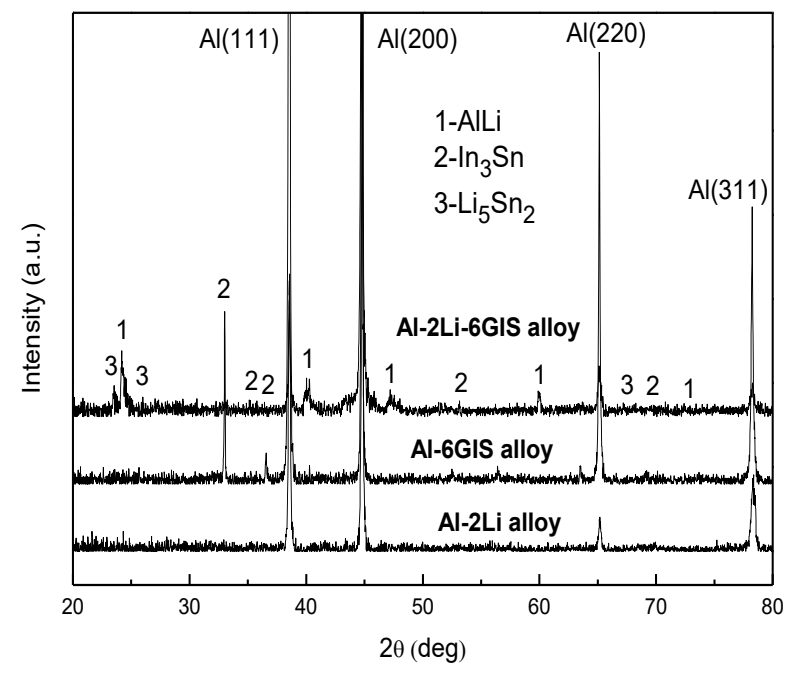

Fig. 1 XRD patterns of different alloys. 

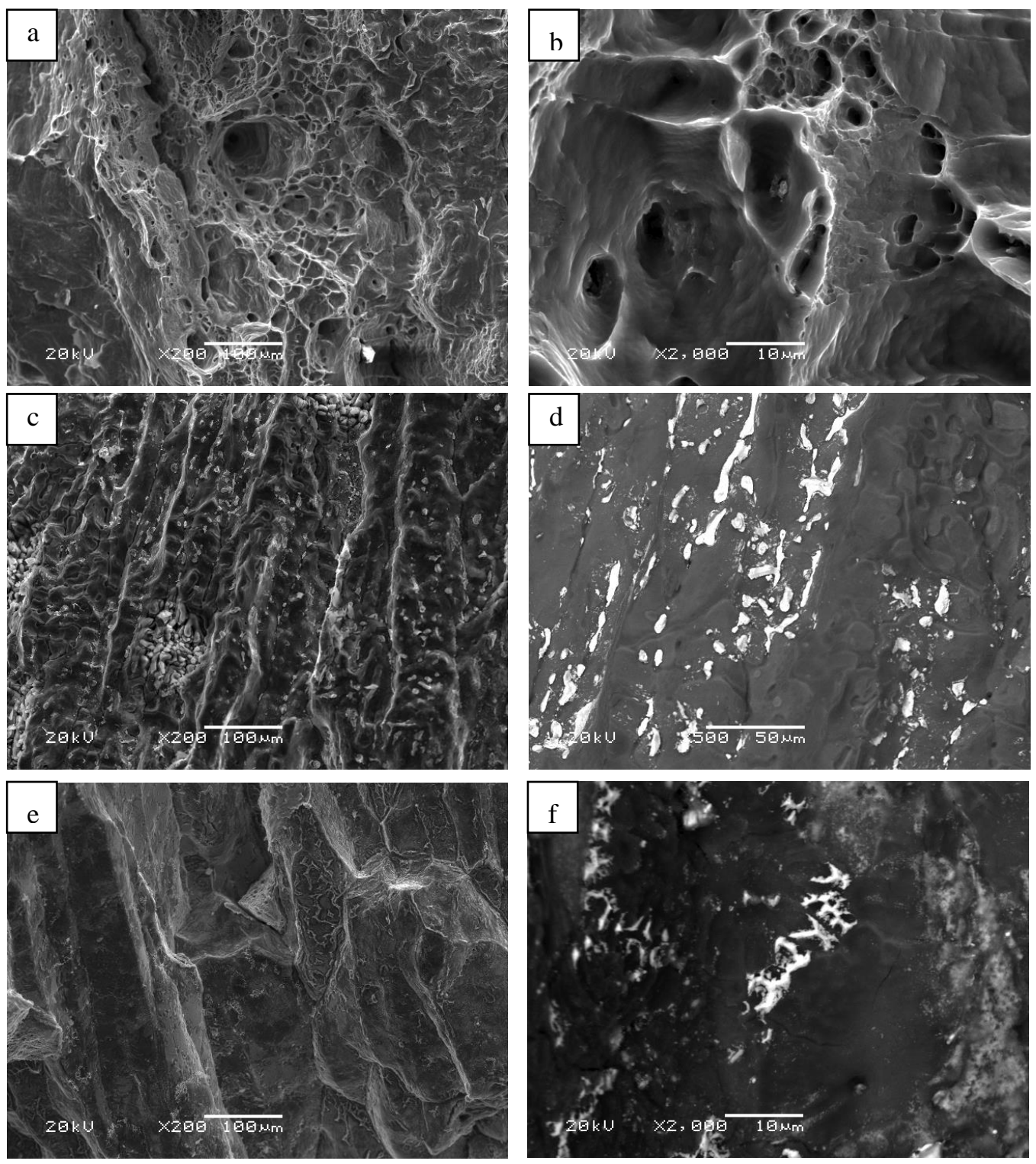

Fig. 2 Fracture surfaces of different alloys: (a), (b) Al-2Li alloy; (c), (d) Al-6GIS alloy; (e), (f) Al-2Li-6GIS alloy. 

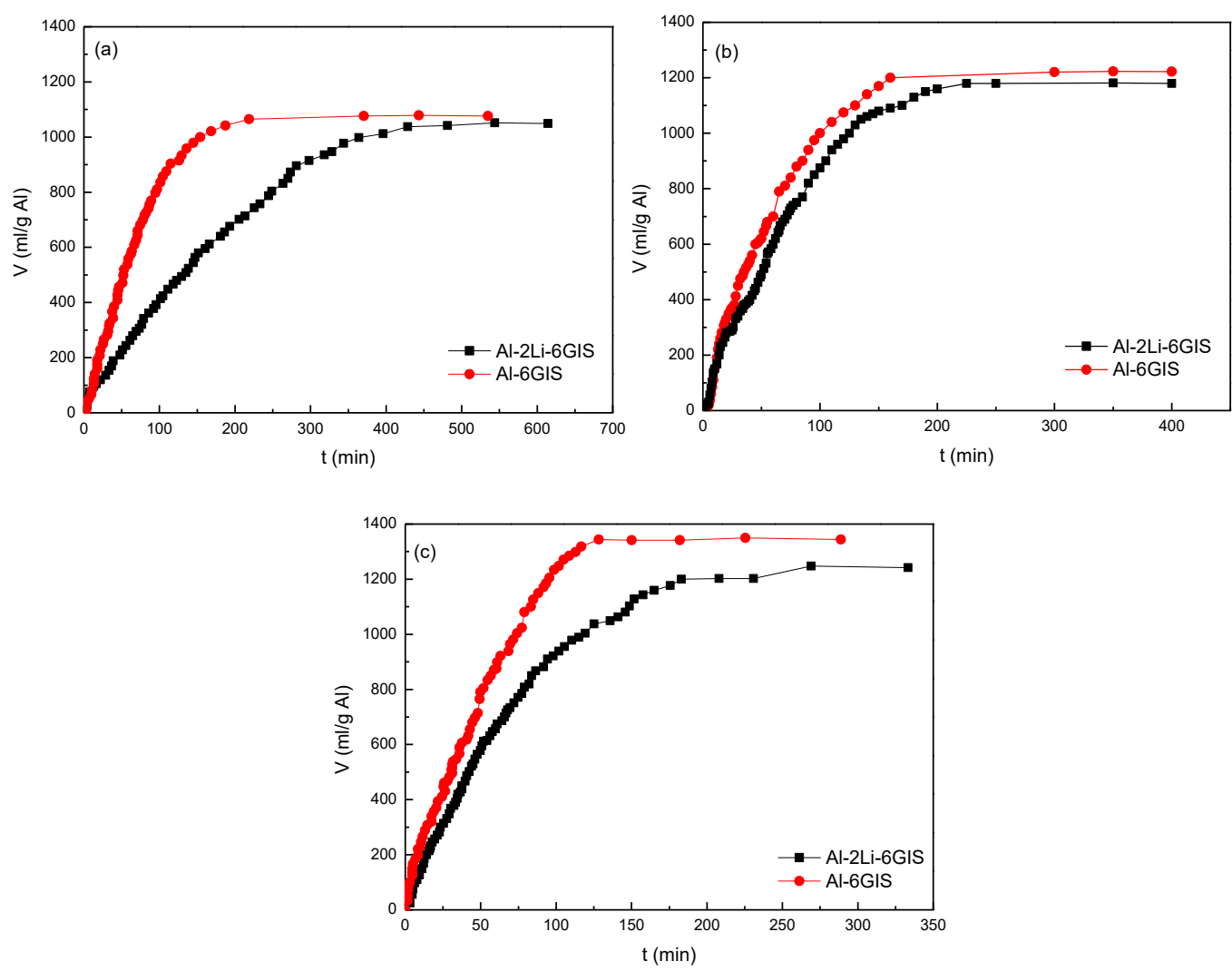

Fig. $3 \mathrm{H}_{2}$ production curves of the Al-6GIS alloy and Al-2Li-6GIS alloy measured at different water temperatures: (a) $50{ }^{\circ} \mathrm{C}$; (b) $60{ }^{\circ} \mathrm{C}$; (c) $70{ }^{\circ} \mathrm{C}$.

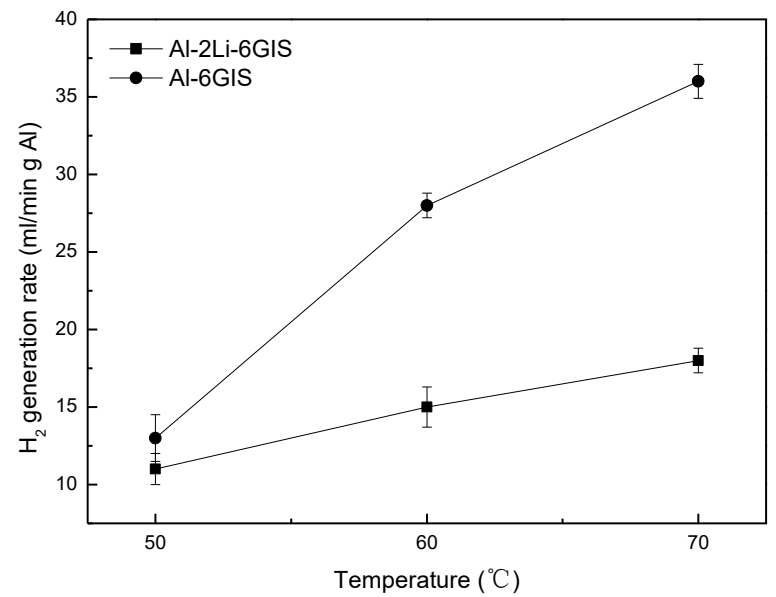

Fig. $4 \mathrm{H}_{2}$ generation rates of the alloys at different water temperatures. 


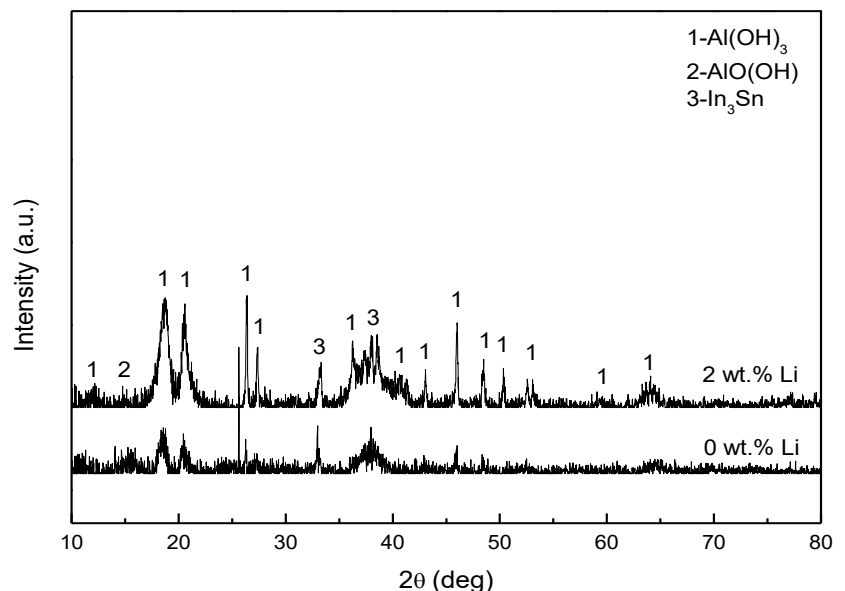

Fig. 5 XRD patterns of the byproducts of the Al-6GIS alloy and Al-2Li-6GIS alloy after the reaction with water at

$60{ }^{\circ} \mathrm{C}$. 
Table 1 Nominal compositions of the prepared alloy ingots (wt.\%).

\begin{tabular}{cccccc}
\hline & \multicolumn{5}{c}{ Element (wt.\%) } \\
\cline { 2 - 6 } Sample & $\mathrm{Al}$ & $\mathrm{Ga}$ & $\mathrm{In}$ & $\mathrm{Sn}$ & $\mathrm{Li}$ \\
\hline Al-2Li alloy & 98 & 0 & 0 & 0 & 2 \\
Al-6GIS alloy & 94 & 3.8 & 1.5 & 0.7 & 0 \\
Al-2Li-6GIS alloy & 92 & 3.8 & 1.5 & 0.7 & 2 \\
\hline
\end{tabular}

Table 2 Compositions of the alloys obtained using EDX.

\begin{tabular}{|c|c|c|c|c|c|c|c|}
\hline \multirow{2}{*}{ Sample } & \multirow{2}{*}{ Spectrum } & \multirow{2}{*}{ Phase } & \multicolumn{5}{|c|}{ Element (at.\%) } \\
\hline & & & $\mathrm{Al}$ & $\mathrm{Ga}$ & In & Sn & $\mathrm{O}$ \\
\hline Al-2Li alloy & 1 & G & 100.00 & 0.00 & 0.00 & 0.00 & 0.00 \\
\hline \multirow[t]{2}{*}{ Al-6GIS alloy } & 2 & G & 57.65 & 1.02 & 0.00 & 0.00 & 41.33 \\
\hline & 3 & GB & 35.57 & 4.63 & 6.04 & 3.62 & 50.14 \\
\hline \multirow[t]{2}{*}{ Al-2Li-6GIS alloy } & 4 & G & 55.21 & 3.26 & 0.00 & 0.00 & 41.23 \\
\hline & 5 & GB & 28.59 & 2.44 & 21.72 & 3.54 & 43.71 \\
\hline
\end{tabular}

G: Al grain, GB: phase (bright white regions).

Table $3 \mathrm{H}_{2}$ yields of the alloys at different water temperatures (\%).

\begin{tabular}{cccc}
\hline Sample & $50{ }^{\circ} \mathrm{C}$ & $60{ }^{\circ} \mathrm{C}$ & $70{ }^{\circ} \mathrm{C}$ \\
\hline Al-6GIS alloy & $86 \%$ & $99 \%$ & $100 \%$ \\
Al-2Li-6GIS alloy & $84 \%$ & $94 \%$ & $100 \%$ \\
\hline
\end{tabular}

